Sains Malaysiana 50(4)(2021): 1175-1186

http://doi.org/10.17576/jsm-2021-5004-27

\title{
COVID-19 Mini-Review: D614G Mutation as an Independent Risk-Factor to the Expression of ACE2 and DPP4 Associated Increased Severity in COVID-19
}

(Ulasan Mini COVID-19: Mutasi D614G sebagai Faktor Risiko Bebas kepada Ekspresi ACE2 dan DPP4 Berkait dengan Peningkatan Keparahan COVID-19)

\author{
Siti Asmaa Mat Jusoh, Parisa Foroozandeh, Lee Yan Fen, Mardani Abdul Halim, Manoj Kumar \\ LASKMANAN \& SHAHARUM SHAMSUDDIN*
}

\begin{abstract}
The novel coronavirus 2019 (COVID-19) has struck more than 99 million people worldwide and had claimed more than 2 million lives as of 23 January 2021, which affecting 221 countries/nations. Until now, the pandemic has not shown signals of slowing down, with no proven vaccine in sight. People are speculating on this unprecedented event. It is well documented that the receptor-binding domain (RBD) of the viral spiked S1 glycoprotein directly bind angiotensinconverting enzyme 2 (ACE2) and dipeptidyl-peptidase-4 (DPP4) or CD26 (cluster of differentiation 26) receptors lead to their entry. The latest evidence demonstrated that SAR-CoV-2 possesses genetic heterogeneity, lead to the existence of a new SAR-CoV-2 variant, such as D614G encoded the spiked S1. The mutation involved changes in amino acid sequence of $D$ (aspartic acid) into $G$ (guanine) at position 614. D614G was reported to confer high infectivity and became the dominant form of the virus globally. Interestingly, current evidence found that D614G protein increases its infectivity dependent on the ACE2 receptor, and its co-binding receptor, DPP4. This proclaims implied to COVID-19 high-risk groups; the aging population and the people with comorbidities; hypertension, cardiovascular disease, and diabetes, which constituted the most of lethal cases, that overexpressed ACE2 and DPP4. The review aims to find an association between COVID-19 infectivity and severity relating to D614G mutation with the expression of ACE2 or DPP4 in these groups. We proposed that D614G mutation and expressions of ACE2 and DPP4 were mutually inclusive for increase infectivity, but not severity in COVID-19's patients.
\end{abstract}

Keywords: Angiotensin-converting enzyme 2 (ACE2); COVID-19; dipeptidyl-peptidase-4 (DPP4); D614G mutation

\section{ABSTRAK}

Koronavirus baru 2019 (COVID-19) telah menyerang lebih daripada 99 juta orang di seluruh dunia dan telah meragut lebih daripada 2 juta nyawa sehingga 23 Januari 2021, yang mempengaruhi 221 negara. Hingga kini, wabak ini tidak menunjukkan tanda-tanda pengurangan tanpa vaksin yang terbukti berkesan. Orang ramai membuat spekulasi mengenai peristiwa yang belum pernah terjadi sebelum ini. Didokumentasikan dengan baik bahawa domain pengikat reseptor (RBD) virus, glikoprotein spiked S atau S1 secara langsung mengikat enzim angiotensin-penukar (ACE2) dan dipeptidil-peptidase-4 (DPP4) atau reseptor CD26 (kelompok pembezaan 26) membawa kepada kemasukan mereka. Bukti terbaru menunjukkan bahawa SARCoV-2 memiliki heterogen genetik, menyebabkan wujudnya varian SAR-CoV-2 baru, seperti D614G yang mengekodkan glikoprotein S1. Mutasi tersebut melibatkan perubahan dalam urutan asid amino D (asid aspartik) menjadi G (guanin) pada kedudukan 614. D614G dilaporkan memberikan kebolehjangkitan tinggi dan menjadi bentuk virus yang dominan pada peringkat global. Menariknya, bukti semasa mendapati bahawa protein D614G meningkatkan kebolehjangkitannya bergantung pada reseptor ACE2 dan reseptor pengikat bersama DPP4. Ini merujuk kepada kumpulan berisiko tinggi COVID-19; populasi penuaan dan orang yang mempunyai kokemorbidan; hipertensi, penyakit kardiovaskular dan diabetes, yang merupakan sebahagian besar daripada kes kematian, yang tinggi ekspresi ACE2 dan DPP4. Ulasan ini bertujuan untuk mencari hubungan antara kebolehjangkitan dan keparahan COVID-19 yang berkaitan dengan mutasi D614G dengan ekspresi ACE2 atau DPP4 dalam kumpulan ini. Kami mencadangkan bahawa mutasi D614G dan ekspresi ACE2 dan DPP4 saling inklusif untuk meningkatkan kebolehjangkitan, tetapi tidak keparahan pada pesakit COVID-19.

Kata kunci: COVID-19; dipeptidil-peptidase-4 (DPP4); enzim angiotensin-penukar 2 (ACE2); mutasi D614G 


\section{INTRODUCTION}

Coronavirus disease 2019 (COVID-19) was firstly emerged in Wuhan, China in late December 2019 by pneumonia-like symptoms, that later on became the pandemic impacted the world populations at every angle. The disease is caused by a newly discovered strain of coronavirus, a severe acute respiratory syndrome coronavirus 2 (SARSCoV-2), and was announced as a public health emergency of international concern (PHEIC) by World Health Organization (WHO) on January 30, 2020.

Coronaviruses (CoVs) belongs to the Coronaviridae family in the Nidovirales order, a long single stranded RNA virus with a diameter of 80-120 nm (Fehr \& Perlman 2015). It features a crown-like spikes on the outer surface of the virus; therefore, it was named as a coronavirus (Shereen et al. 2020). CoVs are divided into four types: $\alpha$-coronavirus $(\alpha-\mathrm{CoV}), \beta$-coronavirus $(\beta-\mathrm{CoV})$, $\delta$-coronavirus $(\delta-\mathrm{CoV})$, and $\gamma$ - coronavirus $(\gamma-\mathrm{CoV})$ (Wang et al. 2020). SARS-CoV-2 belongs to a $\beta$-coronavirus group, is the seventh member of the coronavirus family that infects human beings after SARS-CoV and Middle East Respiratory Syndrome coronavirus (MERS-CoV) (Zheng 2020). Before SARS-CoV-2 was discovered, there were 6 members of human coronavirus ( $\mathrm{HCoV}$ ) identified, which were; HCoV-229E and HCoV-NL63 strains of $\alpha-\mathrm{CoV}$; and $\mathrm{HCoV}-\mathrm{OC} 43$, and $\mathrm{HCoV}-\mathrm{HKU} 1$ of $\beta$-CoV (Elfiky et al. 2017). COVID-19 has relatively high transmissibility in comparison to SARS and MERS diseases, estimated by a basic reproduction number, $\mathrm{R} 0$. It is due to, at the beginning of the COVID-19 outbreak, the median R0 was already 2.28 (2.06-2.52), observed in a group (with 3711 onboard) of the Japanese cruise ship Diamond Princess (Zhang et al. 2020). R0 represents the average number of secondary transmissions or cases from one infected person in an entirely susceptible population in a given time (Remais 2010). If R0 were greater than 1 , it implies that the infection might increase exponentially. In other studies, the R0 of COVID-19 was estimated to be between 2.47 and 2.86 (Wu et al. 2020b), and 2.0 to 3.3 (Majumder \& Mandl 2020) using a different modeling method. In comparison, the R0 value of SARS was about 3.0, ranged 2.2 to 3.6 for a serial interval of 8 to 12 days (Lipsitch et al. 2003).

While the R0 of MERS was about 0.69 in secondary cases (Breban et al. 2013) and ranged 0.8 to 1.3 using the similar study cohort (Cauchemez et al. 2014). However, the R0 value was higher in the course of the hospital outbreaks in Saudi Arabia and South Korea which scored about 2.0 and 5.0 (Choi et al. 2018). The R0 estimation was contingent upon human-to-human transmission and hostto-human transmission over the period of time, in addition to different modelling technologies used (Liu et al. 2020).
It has been found that angiotensin-converting enzyme 2 (ACE2) is the main receptor for human coronavirus HCoV-NL63, SARS-CoV, and also for SARS-CoV-2 (Zhang et al. 2020). Host ACE2 receptors are known to be the eminent site of RBD of the spiked $\mathrm{S}$ protein binding to enter host cell. 83.9 kilobase $(\mathrm{kb})$ of ACE2 gene (NCBI gene ID: 59272) is located at the X chromosome p22.2 and contains 20 exons. ACE2 has the highest expression in small intestine, testis, duodenum, kidney, gall bladder, heart and colon, and intermediately expressed in the lung, brain, liver, and intestine (Kuba et al. 2010). Lung is the primary site of SARS-CoV-2 viral entry (Wang et al. 2020). In the lung, type II alveolar cells have most of ACE2 expression, about $83 \%$ in comparison to its expression in other tissue type, thus, bound more SARS-CoV-2 (Sun et al. 2020). In severe cases, it may lead to acute respiratory distress syndrome (ARDS) (Qian et al. 2013). Dipeptidylpeptidase-4 (DPP4) (NCBI gene ID: 1803) or as known as CD26 is another promising receptor for SARS-CoV-2.

The encoded protein was located at chromosome 2 q24.2 and has as many as 24 coding regions with $81.9 \mathrm{~kb}$ length. DPP4 is widely distributed in many organs, including small intestine, prostate, placenta, kidney, and duodenum. Previously, DPP4 receptor was shown to be convoluted in MERS-CoV efficient entry into the host cell (Earnest et al. 2017). The latest evidence demonstrated a homotrimers structure of SARS-CoV-2 spiked S glycoprotein has a large binding interface to DPP4 receptor (Vankadari \& Wilce 2020) which suggest DPP4 may play a comparable role with ACE2. By a single cell sequencing, it showed a significant correlation of DPP4 which has the most similar expression pattern with ACE2 which represent a similar SARS-CoV-2 entry mechanism (Shang et al. 2020). Detected together were a human aminopeptidase $\mathrm{N}$ (ANPEP) and glutamyl aminopeptidase (ENPEP) as potential receptor of $\mathrm{CoV}$ entries in the same study. So far, ACE2, DPP4, cyclophilin, Ezrin had been reported as co-receptors to bind SARS-CoV-2 S glycoprotein by which ACE2 and DPP4 are the most prominent (Millet et al. 2012; Raj et al. 2013). Current research are focusing on the structural and functional properties of the virus $\mathrm{S}$ glycoprotein as the main player and possible COVID-19 anti-viral drug development (Huang et al. 2020). Up until now, there has been at least 90 vaccines and 50 antibodies are under investigation targeting the virus $\mathrm{S}$ glycoprotein (Cohen 2020; Yu et al. 2020). However, the standpoint change when a point mutation of an aspartic acid (D) to a guanine $(\mathrm{G})$ at amino acid position 614 or D614G mutation of the $\mathrm{S}$ protein was first detected in COVID-19 patients in China. Now a new strain of D614G mutation had emerged, previously circulated in the United Kingdom 
(UK), Italy and North America that become the dominant form of SAR-CoV-2 globally (Stefanelli et al. 2020). This caveat raised a concern whether the current strategy of antibody and vaccine production might work with the existence of this mutation or whether G614 strain is deadlier than the previous strain. Some questions may raise, if the mutation accelerate ACE2 and DPP4 binding affinity to spike S protein or does not give effect at all. After all, what is the central point leading to a higher susceptibility, infectivity, and severity in COVID-19 patients? Almost all available data demonstrated that patients with underlying comorbidities confer a more severe form of COVID-19related illnesses with increased mortality. Comorbidity is defined as a medical condition that exists along with an index condition (Valderas et al. 2009). Hypertension, cardiovascular disease, and diabetes constituted the most common comorbidities in most of the reported cases. The review aims to find an association between COVID-19 infectivity and severity relating to COVID-19 new strains with the human expression of ACE2 or DPP4 in the aging population and people with comorbidities.

\section{MATERIALS AND METHODS}

This review was a narrative review from the published perspective studies assessing the effect of emerging D614G mutation on COVID-19 current state and to discuss on the most prominent risk-factors associated COVID-19 severity and mortality. Research articles, case reports, review articles, editorials, and online databases were included. Literature search was performed in Web of Science, Google Scholar and PubMed databases in February through November 2020 using keywords 'COVID-19', 'COVID-19 RISK-FACTOR', 'D614G MUTATION', with Boolean logical operators ('AND' \& 'OR'). Only articles written in English languages were selected.

\section{RESULTS AND DISCUSSION}

\section{THE D614G MUTATION}

The persistence of the COVID-19 pandemic allowed the accumulations of an acquired mutation by means of natural selection, antigenic drift, or by recent epidemiology pattern (Grubaugh et al. 2020). SAR-CoV-2 are $29.8 \mathrm{~kb}$ in genome length (GeneBank ID: MN908947), consist of 5 '-untranslated region (UTR)-replicase complex (ORF 1a and $1 \mathrm{~b})$, structural proteins (S), envelope (E), membrane (M) and nucleocapsid (N)-3'-UTR (Romano et al. 2020). The spiked S proteins composed of S1 and S2 subunits. $\mathrm{S} 1$ subunit contains RBD responsible to bind ACE2, DPP4 or other surface proteins, while S2 subunit mediate viral cell fusion onto host cell by forming a six-helical bundle via the two-heptad repeat domain (Huang et al. 2020). The spiked $\mathrm{S}$ protein was recognized as a tunnel for selective viral attachment and entry. D614G mutation, is a missense mutation occurred due to changes in amino acid sequence of D (aspartic acid) into $\mathrm{G}$ (guanine) at position 614 of the $\mathrm{S}$ protein. D614G mutation could be arise from a different type of point mutations; a C-to-T mutation in the 5' UTR (position 241 relative to the Wuhan reference sequence), a silent C-to-T mutation at position 3,037, and a C-to-T mutation at position 14,408 (Korber et al. 2020). The accumulation of genetic lesions will result of change in amino acid sequence responsible of variability of clinical presentation of COVID-19. The earliest report by Pachetti et al. (2020) had found eight novel recurrent mutations of SAR-CoV-2 in 220 samples worldwide analyzed from the global initiative on sharing all influenza data (GISAID) database collected in December 2019 until mid-March 2020. The mutation hotspots were located at nucleotide (nt) positions 1397, 2891, 14408, 17746, 17857, 18060, 23403, and 28881. Wang et al. (2020) also characterized 13 variation sites in $1 \mathrm{a}, 1 \mathrm{~b}, \mathrm{~S}, 3 \mathrm{a}, \mathrm{M}, 8$, and $\mathrm{N}$ regions of SAR-CoV-2 genome by which nt 28144 at position 8 and nt 8782 in open reading frame (ORF) la constituted about $30.53 \%$ and $29.47 \%$ mutation rate, respectively. It was reported previously (published in The Lancet) that deletion of 382-nucleotide $(\triangle 382)$ variant of SARCoV-2 which result in truncated ORF $7 \mathrm{~b}$ and ORF 8 were detected in 39 patients in infection cluster in Singapore in between late January and March who returning from Wuhan, China. The analysis conducted showed that these patients had a lower concentration of proinflammatory cytokines, growth factors, and chemokines in comparison with wild-type $\Delta 382$ variant leading to a severe COVID-19 infection (Young et al. 2020). However, since then, from the stringent preventive measures made, the $\Delta 382$ variant was just disappeared with no more COVID patients with the circulating $\Delta 382$. Due to its low transmissibility and infectivity had losses their replicative fitness and eventually attenuated ( $\mathrm{Su}$ et al. 2020). These studies manifested that D614G mutation of SAR-CoV-2 is sustaining its genetic longevity and the sole player in infectivity. The pioneered study published in Cell by Korber et al. (2020) reported a higher infectivity and viral RNA load of a newer version of D614G or G614 of SAR-CoV-2. The report also shows a steady increased in frequency of G614 mutation, and widely distributed in Europe, North America, Oceania and most recently Eastern Asia region. Their in-vitro and clinical data were in agreement with few other studies (Hu et al. 2020; Plante et al. 2020; Wagner et al. 2020). 
The higher transmissibility and frequency of D614G mutation leave a question mark whether this mutation is parallel with the COVID-19 patient's severity. Dr. Nathan D. Grubaugh did not remark G614 is deadlier than its ancestor D614, and suggest risk factors such as age and underlying comorbidities were more notable cause of severity in COVID-19 (Grubaugh et al. 2020). He added that the current COVID-19 vaccine production would not have indirect effect on vaccine effectiveness, which is supported by the current in silico analysis published in October, 2020 (McAuley et al. 2020). In an article currently published in Scientific Report, suggest that D614G mutation of spiked $\mathrm{S}$ protein is neutral to protein function as it is more related to human ACE2 receptor (Isabel et al. 2020). Volz et al. (2020) in Cell give a supporting mark that no association was found between D614G mutation carrier with COVID-19 mortality and clinical severity. Regardless of the sequence variations and mutation hot spots in SAR-CoV-2, Ogawa et al. (2020) made a clearer indication that D614G mutation has higher infectivity in ACE2 receptor-dependent manner, and correlated with less $\mathrm{S} 1$ shedding with greater incorporation of the $\mathrm{S}$ protein into pseudovirion (Zhang et al. 2020). But this would not reflect a higher susceptibility of SAR-CoV-2 in tissue over-expressing ACE2 entirely. As illustrated in Figure 1, D614G and ACE2/DPP4 are different entities. The presence of D614G increases SAR-CoV-2 infectivity independently to ACE2/DPP4 tissue expression. There are no reported indications in pathogenicity and comorbid conditions and non-association with COVID-19 severity, in exception for one report by Volz et al. (2020) showed a slight increase odd of G614 carriage in younger patients in UK population.

\section{INCREASED ACE2 AND DPP4 EXPRESSIONS FOLLOWING AGING CONFER HIGHER INFECTIVITY AND SEVERITY}

Richard L. Sprott had discussed comprehensively on aging as a risk factor for age-related diseases since early $1980 \mathrm{~s}$ (Sprott 2010). Researchers now have made a consensus that increasing age or being older as one of the profound risk factors that can predict prognosis in COVID-19 patients. Accumulating evidence also indicated a high consistency of age as the most compelling risk factor of COVID-19 severity, analyzed from 17 studies (Rod et al. 2020 ). Older patients ( $>60$ years) prone to experience the worst COVID-19 condition, to show no improvement and to eventually died $(\mathrm{p}<0.001)$ (Zhang et al. 2020) which is similar to what WHO had reported. The latest data from a meta-analysis study conducted by Bonanad et al. (2020) as up to May 2020, examining the pattern of mortality rate from COVID-19 in five hotspots countries;
China, Italy, Spain, New York States, and the UK, to find the strongest predictor of COVID-19 deaths. The result showed the mortality rate increase exponentially with age. The mortality rate was $0.3(<1.0)$ in patients aged $<50$ years, and it increases exponentially after that age. As assumed, the mortality rate was $60 \%$ higher in patients with age $>80$ years. Patients age between 60-69 years has the greatest risk of mortality, compared to patients with 50-59 years (Figure 2). The meta-analysis observed significant differences in sample size $(P=0.02)$, mean age $(P=0.01)$, and countries $(P=0.01)$ using Stata, version 14.3 (StataCorp LP, College Station, TX) with heterogeneity, $P=0.001$. This latest statistic would support the earliest report on COVID-19 severity and deaths increasing with age, as cumulated previously in China (Wu et al. 2020c; Zheng et al. 2020), United States (Richardson et al. 2020), Italy (Onder et al. 2020), and UK (Filardi \& Morano 2020). In regards to COVID-19 statistic in children ( $<18$ years), the incidence was $2.1 \%$, where the mortality rate in the same age group was low, $0.3 \%$ (Zare-Zardini et al. 2020). About $90 \%$ children developed asymptomatic, mild to moderate clinical presentation of COVID-19 (Chen et al. 2020).

Two surface receptors that have been found to serve as a mediator in COVID-19 host cell adhesion; ACE2 and DPP4 shown to have a positive correlation with advanced chronological age or senescence (Kim et al. 2017; Sargiacomo et al. 2020). In children, the distribution, maturation, and functioning of the viral receptors were different from adult, confer different sensitivity to the infection (Cristiani et al. 2020). ACE2 and DPP4 shared similarities whereby both expressed their proteins in the lungs, thus, have a similar immunologic response towards COVID-19 infection (Meyerholz et al. 2016). Interestingly, study showed that both ACE2 and DPP4 were overexpressed in mice myofibroblast (concerning of cell undergone senescence and pro-fibrotic in wound healing) (Guy et al. 2008; Mah et al. 2017). Hence, COVID-19 increasing severity and death following chronological age is simply due to naturally overload senescence lung cells, an eminent target for COVID-19 viral infection. Various mechanisms are known to be convoluted in aging processes, such as oxidative stress, dysregulated function of a mitochondria, changes in calcium regulation, inflammation, lipid oxidation, including the activation of renin-angiotensin system (RAS) cascade (Kovacic et al. 2011). ACE2 is an inhibitor of the RAS signaling which is upregulated in premature and replicative senescence (Sonia et al. 2015). Vascular aging was modulated by the RAS pathway by increase the number of senescence associated $\beta$-galactosidase, pro-fibrotic mediators and decrease the expression of AT2 receptor (AT2R) and G-protein coupled Mas receptor (MasR) (Kim et al. 
2018). In senescence or aging cells, the ACE2 was abundantly present causing cellular Angiotensin II (Ang II) to accumulate leading to the activation of RAS cascade. ACE2 inhibitor (ACE2i) works by reducing proinflammatory Ang II thus reducing the course of infection and severity in COVID-19 patients (Figure 3). Whilst, DPP4 is best described in glucose metabolism whereby it inactivates two incretins hormones; glucose-dependent insulinotropic peptide (GIP) and glucagon-like peptide-1 (GLP-1). Incretins stimulate rapid release of insulin after meals. In normal homeostasis, elevated DPP4 regulates glucose metabolism, which however in aging cells, its elevation caused impairment of glucose metabolism and other associated metabolism leading to hyperglycemia in elderly. Therefore, DPP4 inhibitor (DPP4i) (such as sitagliptin) beside its anti-glycemic could be recapitulate to enhance cellular proliferation (Scott 2017) and restored senescence cell after DPP4 knockout (Kim et al. 2017).
Another aspect to initially dissect is, if there were a positive association between plausible host genetic factor to SAR-CoV-2 susceptibility and pathogenesis. Previous studies with SAR-CoV had proposed that the candidate gene approach should be implemented to investigate the genetic contribution factors with a known or dubitable role in the infection, such as ACE2 and DPP4. The studies conducted in China and Vietnam showed no evidence of association of ACE2 genetic variants with SARS susceptibility (Ovsyannikova et al. 2020). However, the newest report showed a significant correlation of ACE2 expression with interferon lambda (IFNL) 3 and IFNL4, as well as age in infected liver tissues by genome-wide association study (GWAS) (Ansari et al. 2020). This finding demonstrated that hunting for gene that was associated with ACE2 or other known indicator (as such age) served as a complementary method for COVID-19 patients' prognosis.

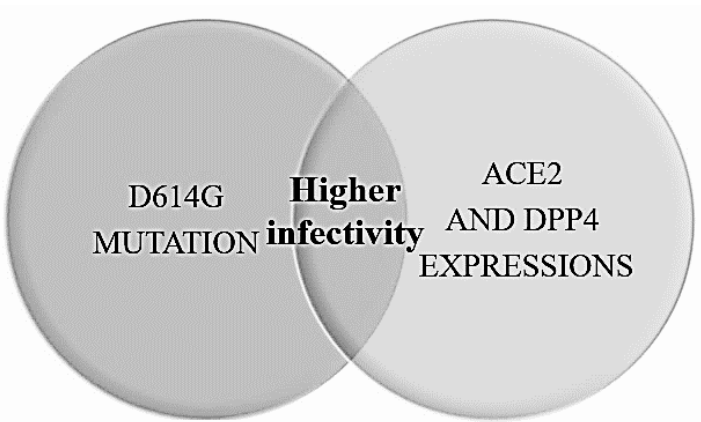

- Slightly increase odds of G614 carriage in younger patients

- No reported indication in pathogenicity and comorbid conditions

- No proven association with COVID-19 severity

- Higher expression in aging population

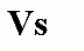

- Higher expression underlying comorbid conditions

- Associated with COVID-19 severity

FIGURE 1. Proposed relationship of D614G mutation and expressions of ACE2 and DPP4 of COVID-19 related infectivity and severity

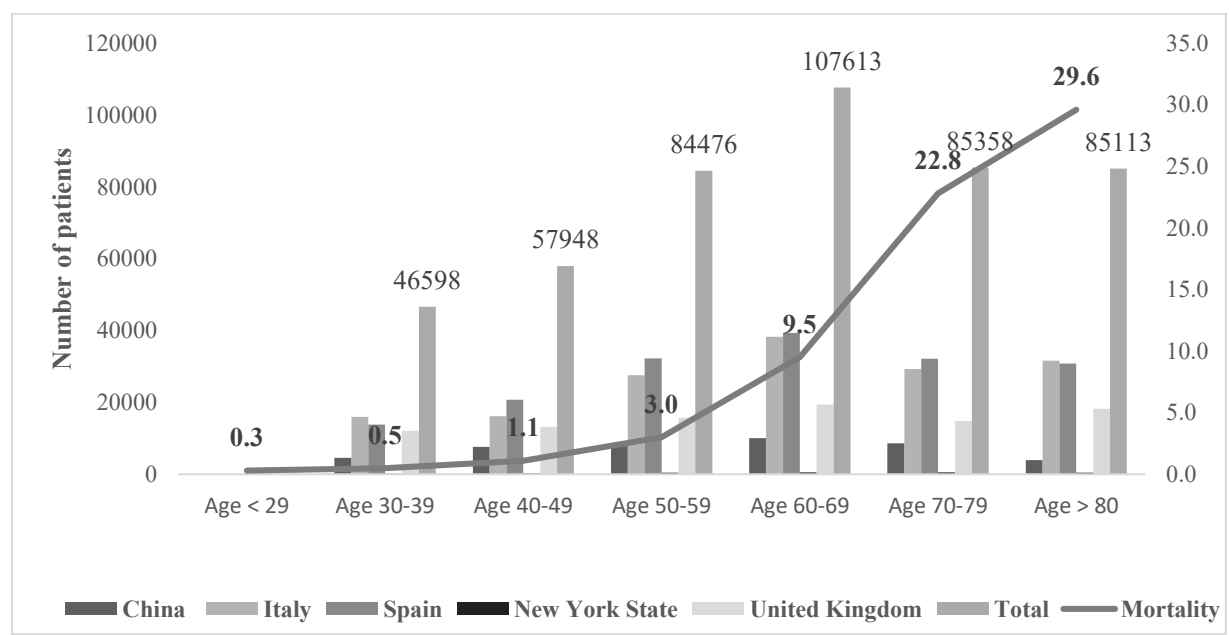

FIGURE 2. The number of patients with COVID-19 according to age groups and crude mortality rate (\%) (line graph) 


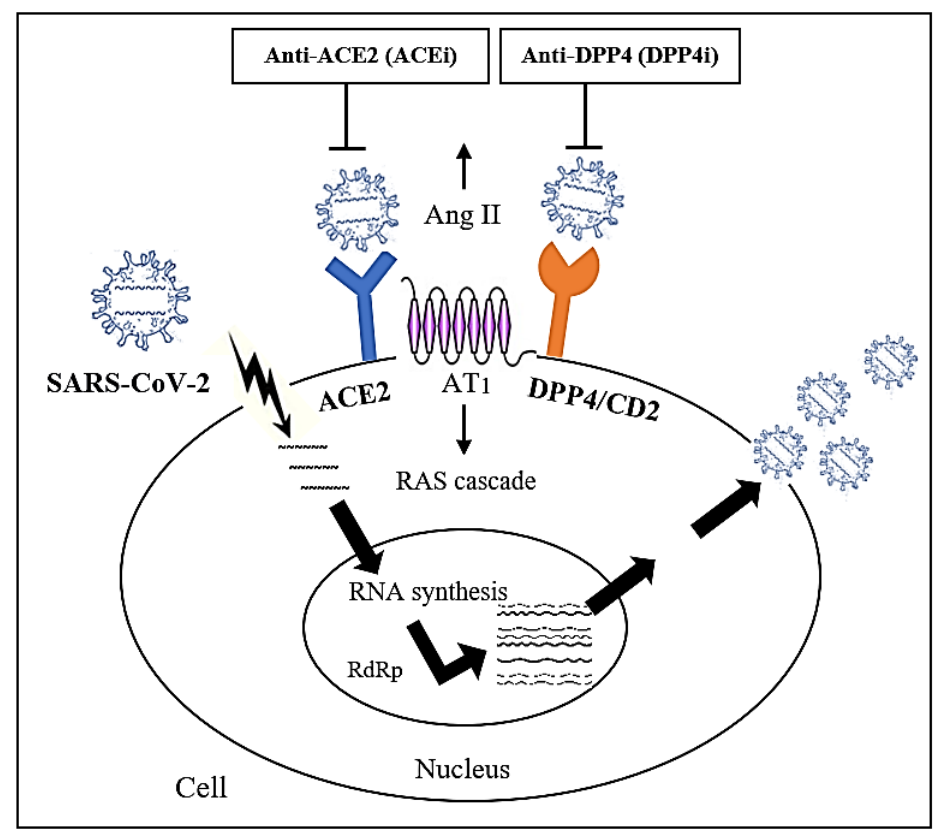

FIGURE 3. Schematic diagram of proposed biological mechanism of SAR-CoV2 particles entry into the host senescence lung cells. The virus spiked S1 binds to ACE2 and DPP4/CD26 receptors host cells which promotes their entry. In the nucleus, new viral RNAs were synthesized, catalyzed by RNA-dependent RNA polymerase (RdRp) to produce more viral RNAs. ACE inhibitor (ACEi) and DPP4 inhibitor (DPP4i) may be targeted to curb the infection

Higher expression of ACE2 and DPP4 in hypertensive, cardiovascular disease, and diabetes patients promoted higher COVID-19 susceptibility, infectivity, and severity.

COVID-19 patients with long-standing chronic illnesses such as hypertension, cardiovascular disease, and diabetes are considered to be the most vulnerable shown by the high mortality rate from this group in all reported clinical data. The eminent report in China indicated that hypertension, cardiovascular disease and diabetes represented the most common comorbidities, that account for $30 \%, 19 \%$ and $8 \%$ of total cases (Zhou et al. 2020). They are more likely to be admitted to the intensive care unit (ICU) and to develop severe respiratory distress (Wu et al. 2020a). Again, RAS cascade is the amateur in promoting pro-inflammatory response in these comorbid conditions.

\section{HYPERTENSION}

Hypertension rendered one of the major comorbidities in COVID-19 patients, both with controlled and uncontrolled high blood pressure (Schiffrin et al. 2020). COVID-19 spiked S proteins bind to ACE2 three-dimensional (3D) structure, expressed at a high level at type 11 alveolar of the lung (Yan et al. 2020). The virus has a high affinity to bind with alveolar pneumocytes that has surface expression ACE2 and its upregulation accelerates viral replication (Zhuang et al. 2020). Upon binds to ACE2, SARS-COV-2 caused depletion in ACE2 expression in host cells, resulted in over-activating Ang II leading to acute lung injury or ARDS (Imai et al. 2010). The recently discovered ACE2 counterbalanced the activity of ACE1 by converting Ang II into Ang (1-7), which acts on the MasR to attenuate proliferation, fibrosis and acted as a vasodilator to reduce inflammatory action caused by Ang II by mitogen-activated protein kinase (MAPK) signaling (Meng et al. 2013) (Figure 4). In the case of COVID-19 entry, when virus bound to the ACE2 receptor, the binding subsequently prevents ACE2 to metabolize Ang II resulted in elevated Ang II and injured cells. 


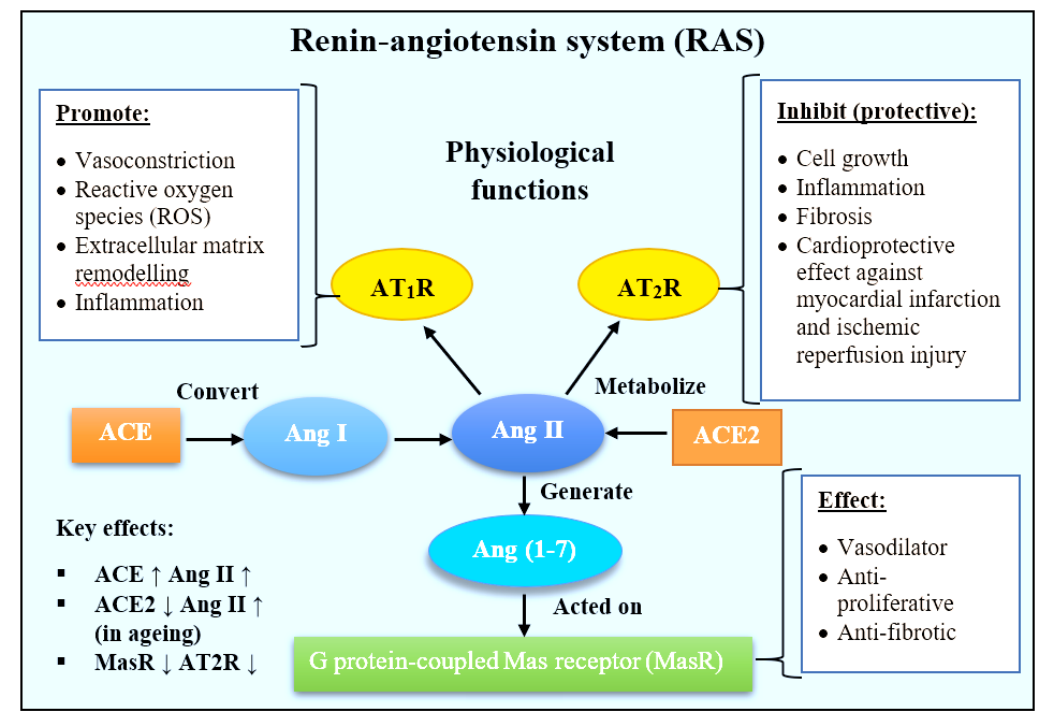

FIGURE 4. Schematic diagram of the renin-angiotensin system (RAS) in the regulation of hypertension. Angiotensin II (Ang II) served as the main effector, acted on AT1 receptor (AT1R) or AT2R

\section{CARDIOVASCULAR DISEASE}

Many patients with COVID-19 have underlying cardiovascular disease (CVD) or developed acute cardiac injury during the course of the illness (Bansal 2020). The loss of ACE2 was in proportion with Ang II elevated level in the plasma and tissues which mediate the production of oxidative stress and inflammation (Oudit et al. 2007). The production of Ang (1-7) also reflects the Ang II activity when ACE2 level is high. Ang (1-7) activities were decreased when the activity of Ang II was suppressed by ACE2 inhibitor (Zisman et al. 2003). The ACE2 was elevated in COVID-19 patients with pre-existing cardiac injury due to angiotensin II receptor blockers (ARBs) treatment (Gallagher et al. 2008). Upon SARS-CoV-2 binds to ACE2 receptor, Ang II was rapidly produced created inflammatory storms through altered RAS signaling leads to acute myocardial injury. Acute myocardial injury is the most commonly described cardiovascular complication and a very reliable negative prognostic marker in COVID-19 patients (Wang et al. 2020).

\section{DIABETES}

Diabetes is a chronic inflammatory condition which cause multiple metabolic and vascular abnormalities, whilst affecting the response to pathogens. It served one of the dominant causes of morbidity and mortality globally which highly affecting the overall survival of the patients with COVID-19, mainly via microvascular and macrovascular complications (Williams et al. 2020). DPP4 or CD26 learned to play roles in glucose and insulin metabolisms. Higher DPP4 level in visceral adipose tissue was associated with adipocyte inflammation and insulin resistance (Iacobellis 2020). DPP4 caused dysregulation of immune response by stimulating pro-inflammatory pathways, such as the activating $\mathrm{T}$ cell and nuclear factor-kappa activated B cell (NF-KB). Besides, ACE2 itself is a comrade in diabetic patients. Study has reported an increased in ACE2 expression in a diabetic rat that disrupts the balance of the RAS cascade (Patel et al. 2013). The RAS and Ang II have shown to be implicated in insulin resistance and diabetes. The adopted medication against type- 2 diabetes such as, statins and proliferator-activated receptor gamma (PPAR- $\gamma$ ) agonists increased ACE2 expression, thus, provide higher anchor for higher binding of SARS-CoV2 (Filardi \& Morano 2020). Asia Research News published on July 6, 2020, the Chinese University of Hong Kong, reported through an advanced statistical analysis of Mendelian randomization found that ACE2 is a key receptor for COVID-19 and its high expression was corresponding to 
high susceptibility to the infection. The study also reported a significant and positive correlation of ACE2 expression across many diabetes datasets (Rao et al. 2020).

\section{CONCLUSION}

The world is now reaching the final stage of "flatten the curve' of COVID-19. Censorious containment measures have shown to curb the spread, save lives, and reduce the pressure on healthcare system. However, the extent and duration of infection are uncertain. In the past few months, we have seen a post-COVID impact, especially in economy, education and health system. Changes in health system was rather grim which affected all disease spectrums. It was discussed here the SAR-CoV-2 spiked S1 glycoprotein that undergone D614G mutation and cell surface receptors associated with it. The recently identified SAR-CoV-2 variants; 501.V2 (found in October 2020), originated from South Africa, and B117 or VUI-202012/01 (found in December 2020), originated from the UK have raised high concern in a way how these genetic heterogeneities would affect disease severity. But there is no information on the effect of these variants on the disease severity. High expression of ACE2 and DPP4 in tissues are the predictive of the increased viral load and hence disease severity. This is especially pertinent for the aging population and people with comorbidities; hypertension, cardiovascular disease, and diabetes which had over-expressed ACE2 and DPP4. In case of COVID-19, warded patients with the underlying hypertension, cardiovascular disease and diabetes impinged the most. In a conclusion, D614G mutation far did not reflect the severity in COVID-19 patients. There is a tiny possibility that the spiked S1 protein eventually losses its binding domain for ACE2 or DPP4 due to mutations and bind other novel surface receptors related to other physiological response. Whether or not the mutant D614G of spiked S1 protein increase severity in COVID-19 patients, its RBD for ACE2, DPP4 or other surface receptors had showed perceptible and more dominant caused lead to disease severity. With the evolving SAR-CoV-2 spiked S1 protein, various new mutation types could be observed sooner or later. Therefore, understanding the interplay between SAR-CoV-2 spiked S1 and its binding receptors or any part of the virus that cause the disease, by a continuous research is more required for the development of vaccines or prophylaxis agents against COVID-19 which eventually can lead to an establishment of point-of-care testing for COVID-19.

\section{ACKNOWLEDGEMENTS}

USM-RIKEN Interdisciplinary Collaboration for Advanced Sciences (URICAS) for providing research initiative platform.

\section{REFERENCES}

Ansari, M.A., Marchi, E., Ramamurthy, N., Aschenbrenner, D., Hackstein, C.P., Lin, Shang-Kuan., Bowden, R., Sharma, E., Pedergnana, V., Venkateswaran, S., Kugathasan, S., Mo, A., Gibson, G., Cooke, G., McLauchlan, J., Barnes, E., Baillie, J.K., Teichmann, S., Mentzer, A., Todd, J., Knight, J., Uhlig, H. \& Klenerman, P. 2020. Negative regulation of ACE2 by interferons in vivo and its genetic control. doi: https://doi.or g/10.1101/2020.04.26.20080408.

Bansal, M. 2020. Cardiovascular disease and COVID-19. Diabetes \& Metabolic Syndrome 14(3): 247-250.

Breban, R., Riou, J. \& Fontanet, A. 2013. Interhuman transmissibility of Middle East respiratory syndrome coronavirus: Estimation of pandemic risk. Lancet (London, England) 382(9893): 694-699.

Cauchemez, S., Fraser, C., Van Kerkhove, M.D., Donnelly, C.A., Riley, S., Rambaut, A., Enouf, V., der Werf, S. \& Ferguson, N.M. 2014. Middle East respiratory syndrome coronavirus: Quantification of the extent of the epidemic, surveillance biases, and transmissibility. The Lancet Infectious Diseases 14(1): 50-56

Chen, D., Li, X., Song, Q., Hu, C., Su, F. \& Dai, J. 2020. Hypokalemia and clinical implications in patients with coronavirus disease 2019 (COVID-19). medRxiv 2(27): 20028530 .

Choi, S., Jung, E., Choi, B.Y., Hur, Y.J. \& Ki, M. 2018. High reproduction number of Middle East respiratory syndrome coronavirus in nosocomial outbreaks: Mathematical modelling in Saudi Arabia and South Korea. Journal of Hospital Infection 99(2): 162-168.

Cohen, J. 2020. COVID-19 shot protects monkeys. Science 368(6490): 456.

Cristiani, L., Mancino, E., Matera, L., Nenna, R., Pierangeli, A., Scagnolari, C. \& Midulla, F. 2020. Will children reveal their secret? The coronavirus dilemma. European Respiratory Journal 55(4): 2000749.

Earnest, J.T., Hantak, M.P., Li, K., McCray, P.B., Perlman, S. \& Gallagher, T. 2017. The tetraspanin CD9 facilitates MERScoronavirus entry by scaffolding host cell receptors and proteases. PLoS Pathogens 13(7): e1006546.

Elfiky, A.A., Mahdy, S.M. \& Elshemey, W.M. 2017. Quantitative structure-activity relationship and molecular docking revealed a potency of anti-hepatitis $\mathrm{C}$ virus drugs against human corona viruses. Journal of Medical Virology 89(6): 1040-1047.

Fehr, A.R. \& Perlman, S. 2015. Coronaviruses: An overview of their replication and pathogenesis. In. Methods in Molecular Biology, edited by Maier, H. \& Britton, P. Volume 1282. New York: Humana Press.

Filardi, T. \& Morano, S. 2020. COVID-19: Is there a link between the course of infection and pharmacological agents in diabetes? Journal of Endocrinological Investigation 43(8): 1053-1060.

Gallagher, P.E., Ferrario, C.M. \& Tallant, E.A. 2008. Regulation of ACE2 in cardiac myocytes and fibroblasts. American Journal of Physiology 295(6): H2373-H2379. 
Grubaugh, N.D., Hanage, W.P. \& Rasmussen, A.L. 2020. Making sense of mutation: What D614G means for the COVID-19 pandemic remains unclear. Cell 182(4): 794-795.

Guy, J.L., Lambert, D.W., Turner, A.J. \& Porter, K.E. 2008. Functional angiotensin-converting enzyme 2 is expressed in human cardiac myofibroblasts. Experimental Physiology 93(5): 579-588.

Hu, J., He, C.L., Gao, Q.Z., Zhang, G.J., Cao, X.X., Long, Q.X., Deng, H.J., Huang, L.Y., Chen, J., Wang, K., Tang, N. \& Huang, A.L. 2020. D614G mutation of SARS-CoV-2 spike protein enhances viral infectivity. bioRxiv doi: https://doi. org/10.1101/2020.06.20.161323.

Huang, Y., Yang, C., Xu, X.F., Xu, W. \& Liu, S.W. 2020. Structural and functional properties of SARS-CoV-2 spike protein: Potential antivirus drug development for COVID-19. Acta Pharmacologica Sinica 41: 1141-1149.

Iacobellis, G. 2020. COVID-19 and diabetes: Can DPP4 inhibition play a role? Diabetes Research and Clinical Practice 162: 108125

Imai, Y., Kuba, K., Ohto-Nakanishi, T. \& Penninger, J.M. 2010. Angiotensin-converting enzyme 2 (ACE2) in disease pathogenesis. Circulation Journal 74(3): 405-410.

Isabel, S., Graña-Miraglia, L., Gutierrez, J.M., BundalovicTorma, C., Groves, H.E., Isabel, M.R., Eshaghi, AliReza., Patel, S.N., Gubbay, J.B., Poutanen, T., Guttman, D.S. \& Poutanen, S.M. 2020. Evolutionary and structural analyses of SARS-CoV-2 D614G spike protein mutation now documented worldwide. Scientific Reports 10(1): 14031.

Kim, E.N., Kim, M.Y., Lim, J.H., Kim, Y., Shin, S.J., Park, C.W., Kima, Y.S., Sik, Y., Hye, C., Yoon, E. \& Choi, B.S. 2018. The protective effect of resveratrol on vascular aging by modulation of the renin-angiotensin system. Atherosclerosis 270: 123-131.

Kim, K.M., Noh, J.H., Bodogai, M., Martindale, J.L., Yang, X., Indig, F.E., Basu, S.K., Ohnuma, K., Morimoto, C., Johnson, P.F., Biragyn, A., Abdelmohsen, K. \& Gorospe, M. 2017. Identification of senescent cell surface targetable protein DPP4. Genes and Development 31(15): 1529-1534.

Korber, B., Fischer, W.M., Gnanakaran, S., Yoon, H., Theiler, J., Abfalterer, W., Hengartner, N., Giorgi, E.E., Bhattacharya, T., Foley, B., Hastie, K.M., Parker, M.D., Partridge, D.G., Evans, C.M., Freeman, T.M. \& Montefiori, D.C. 2020. Tracking changes in SARS-CoV-2 spike: Evidence that D614G increases infectivity of the COVID-19 Virus. Cell 182(4): 812-827.

Kovacic, J.C., Moreno, P., Nabel, E.G., Hachinski, V. \& Fuster, V. 2011. Cellular senescence, vascular disease, and aging: Part 2 of a 2-part review: Clinical vascular disease in the elderly. Circulation 123(17): 1900-1910.

Kuba, K., Imai, Y., Ohto-Nakanishi, T. \& Penninger, J.M. 2010. Trilogy of ACE2: A peptidase in the renin-angiotensin system, a SARS receptor, and a partner for amino acid transporters. Pharmacology \& Therapeutics 128(1): 119128.

Lipsitch, M., Cohen, T., Cooper, B., Robins, J.M., Ma, S., James, L., Gopalakrishna, G., Chew, S.K., Tan, C.C., Samore, M.H., Fisman, D. \& Samore, M.H. 2003. Transmission dynamics and control of severe acute respiratory syndrome. Science 300(5627): 1966-1970

Liu, J., Xie, W., Wang, Y., Xiong, Y., Chen, S., Han, J. \& Wu, Q. 2020. A comparative overview of COVID-19, MERS and SARS: Review article. International Journal of Surgery (London, England) 81: 1-8.

Mah, W., Jiang, G., Olver, D., Gallant-Behm, C., Wiebe, C., Hart, D.A., Koivisto, L., Larjava, H. \& Häkkinen, L. 2017. Elevated CD26 expression by skin fibroblasts distinguishes a profibrotic phenotype involved in scar formation compared to gingival fibroblasts. American Journal of Pathology 187(8): 1717-1735.

Majumder, M. \& Mandl, K.D. 2020. Early transmissibility assessment of a novel coronavirus in Wuhan, China. SSRN eJournal: 1-7. http://dx.doi.org/10.2139/ssrn.3524675.

McAuley, A.J., Kuiper, M.J., Durr, P.A., Bruce, M.P., Barr, J., Todd, S., Au, G.G., Blasdell, K., Tachedjian, M., Lowther, S., Marsh, G.A., Edwards, S., Poole, T., Layton, R., Riddell, S.J., Drew, T.W., Druce, J.D., Smith, T.R.F., Broderick, K.E. \& Vasan, S.S. 2020. Experimental and in silico evidence suggests vaccines are unlikely to be affected by D614G mutation in SARS-CoV-2 spike protein. npj Vaccines 5(1): 96

Meng, Y., Yu, C.H., Li, W., Li, T., Luo, W., Huang, S., Wu, P.S., Cai, S.X. \& Li, X. 2013. Angiotensin-converting enzyme 2/ angiotensin-(1-7)/mas axis protects against lung fibrosis by inhibiting the MAPK/NF-kB pathway. American Journal of Respiratory Cell and Molecular Biology 50(4): 723-736.

Meyerholz, D.K., Lambertz, A.M. \& McCray, P.B. 2016. Dipeptidyl peptidase 4 distribution in the human respiratory tract implications for the Middle East respiratory syndrome. American Journal of Pathology 186(1): 78-86.

Millet, J.K., Kien, F., Cheung, C.Y., Siu, Y.L., Chan, W.L., Li, H., Leung, H.L., Jaume, M., Bruzzone, R., Peiris, J.S.M., Altmeyer, R.M. \& Nal, B. 2012. Ezrin interacts with the SARS coronavirus Spike protein and restrains infection at the entry stage. PLoS ONE 7(11): e49566-e49566.

Ogawa, J., Zhu, W., Tonnu, N., Singer, O., Hunter, T., Ryan, A.L. \& Pao, G.M. 2020. The D614G mutation in the SARS-CoV2 Spike protein increases infectivity in an ACE2 receptor dependent manner. bioRxiv doi: 10.1101/2020.07.21.214932.

Onder, G., Rezza, G. \& Brusaferro, S. 2020. Case-fatality rate and characteristics of patients dying in relation to COVID-19 in Italy. JAMA 323(18): 1775-1776.

Oudit, G.Y., Kassiri, Z., Patel, M.P., Chappell, M., Butany, J., Backx, P.H., Tsushima, R.G., Scholey, J.W., Khokha, R. \& Penninger, J.M. 2007. Angiotensin II-mediated oxidative stress and inflammation mediate the age-dependent cardiomyopathy in ACE2 null mice. Cardiovascular Research 75(1): 29-39.

Ovsyannikova, I.G., Haralambieva, I.H., Crooke, S.N., Poland, G.A. \& Kennedy, R.B. 2020. The role of host genetics in the immune response to SARS-CoV-2 and COVID-19 susceptibility and severity. Immunological Reviews 296(1): 205-219.

Pachetti, M., Marini, B., Benedetti, F., Giudici, F., Mauro, E., Storici, P., Masciovecchio, C., Angeletti, S., Ciccozzi, M., Gallo, R.C., Zella, D. \& Ippodrino, R. 2020. Emerging 
SARS-CoV-2 mutation hot spots include a novel RNAdependent-RNA polymerase variant. Journal of Translational Medicine 18(1): 179.

Patel, V.B., Parajuli, N. \& Oudit, G.Y. 2013. Role of angiotensinconverting enzyme 2 (ACE2) in diabetic cardiovascular complications. Clinical Science 126(7): 471-482.

Plante, J.A., Liu, Y., Liu, J., Xia, H., Johnson, B.A., Lokugamage, K.G., Zhang, X., Muruato, A.E., Zou, J., Fontes-Garfias, C.R., Mirchandani, D., Scharton, D., Bilello, J.P., Ku, Z., An, Z., Kalveram, B., Freiberg, A.N., Menachery, V.D., Xie, X., Plante, K.S., Weaver S.C. \& Shi, P.Y. 2020. Spike mutation D614G alters SARS-CoV-2 fitness. Nature 592: 116-121.

Qian, Z., Travanty, E.A., Oko, L., Edeen, K., Berglund, A., Wang, J., Ito, Y., Holmes, K.V. \& Mason, R.J. 2013. Innate immune response of human alveolar type II cells infected with severe acute respiratory syndrome-coronavirus. American Journal of Respiratory Cell and Molecular Biology 48(6): 742-748.

Raj, V.S., Mou, H., Smits, S.L., Dekkers, D.H.W., Müller, M.A., Dijkman, R., Muth, D., Demmers, J.A.A., Zaki, Ali., Fouchier, R.A.M., Thiel, V., Drosten, C., Rottier, P.J.M., Osterhaus, A.D.M.E., Bosch, B.J. \& Haagmans, B.L. 2013. Dipeptidyl peptidase 4 is a functional receptor for the emerging human coronavirus-EMC. Nature 495(7440): 251-254.

Rao, S., Lau, A. \& So, H.C. 2020. Exploring diseases/traits and blood proteins causally related to expression of ACE2, the putative receptor of SARS-CoV-2: A Mendelian Randomization analysis highlights tentative relevance of diabetes-related traits. Diabetes Care 43(7): 1416.

Remais, J. 2010. Modelling environmentally-mediated infectious diseases of humans: Transmission dynamics of schistosomiasis in China. In Modelling Parasite Transmission and Control, edited by Michael, E. \& Spear, R.C. Volume 674. New York: Springer. pp. 79-98.

Richardson, S., Hirsch, J.S., Narasimhan, M., Crawford, J.M., McGinn, T. \& Davidson, K.W. 2020. Presenting characteristics, comorbidities, and outcomes among 5700 patients hospitalized with COVID-19 in the New York City Area. JAMA 323(20): 2052-2059.

Rod, J.E., Trespalacios, O.O. \& Cortes, J.R. 2020. A brief-review of the risk factors for covid-19 severity. Revista de Saude Publica 54: 60

Romano, M., Ruggiero, A., Squeglia, F., Maga, G. \& Berisio, R. 2020. A structural view of SARS-CoV-2 RNA replication machinery: RNA synthesis, proofreading and final capping. Cells 9(5): 1267.

Sargiacomo, C., Sotgia, F. \& Lisanti, M.P. 2020. COVID-19 and chronological aging: Senolytics and other anti-aging drugs for the treatment or prevention of corona virus infection? Aging 12(8): 6511-6517.

Schiffrin, E.L., Flack, J.M., Ito, S., Muntner, P. \& Webb, R.C. 2020. Hypertension and COVID-19. American Journal of Hypertension 33(5): 373.

Scott, L.J. 2017. Sitagliptin: A review in Type 2 diabetes. Drugs 77(2): 209-224.

Shang, J., Wan, Y., Luo, C., Ye, G., Geng, Q., Auerbach, A. $\&$ Li, F. 2020. Cell entry mechanisms of SARS-CoV-2. Proceedings of the National Academy of Sciences 117(21): 11727.
Shereen, M.A., Khan, S., Kazmi, A., Bashir, N. \& Siddique, R. 2020. COVID-19 infection: Origin, transmission, and characteristics of human coronaviruses. Journal of Advanced Research 24: 91-98.

Sonia, K.B., Noureddine, I.K., Ribeiro, T.P., Silva, G.C., Abbas, M., Kheloufi, M., Lee, J.O., Toti, F., Auger, C. \& Schini, K. 2015. Redox-sensitive induction of the local angiotensin system promotes both premature and replicative endothelial senescence: Preventive effect of a standardized crataegus extract. The Journals of Gerontology Series A 71(12): 15811590.

Sprott, R.L. 2010. Biomarkers of aging and disease: Introduction and definitions. Experimental Gerontology 45(1): 2-4.

Stefanelli, P., Faggioni, G., Lo Presti, A., Fiore, S., Marchi, A., Benedetti, E., Fabiani, C., Anselmo, A., Ciammaruconi, A., Fortunato, A., De Santis, R., Fillo, S., Capobianchi, M.R., Gismondo, M.R., Ciervo, A., Rezza, G., Castrucci, M.R., Lista, F. \& ISS COVID-19 Study Group. 2020. Whole genome and phylogenetic analysis of two SARS-CoV-2 strains isolated in Italy in January and February 2020: Additional clues on multiple introductions and further circulation in Europe. Eurosurveillance 25(13): 2000305.

$\mathrm{Su}$, Y.C.F., Anderson, D.E., Young, B.E., Linster, M., Zhu, F., Jayanthi Jayakumar, Zhuang, Y., Shirin Kalimuddin, Low, J.G.H., Tan, C.W., Chia, W.N., Mak, T.M., Octavia, S., Chavatte, J.M., Lee, R.T.C., Surinder Pada, Tan, S.Y., Sun, L., Yan, G.Z., Maurer-Stroh, S., Mendenhall, I.H., Leo, Y.S., Lye, D.C., Wang, L.F. \& Smith, G.J.D. 2020. Discovery and genomic characterization of a 382-nucleotide deletion in ORF7b and ORF8 during the early evolution of SARS-CoV-2. mBio 11(4): e01610-01620.

Sun, P., Lu, X., Xu, C., Sun, W. \& Pan, B. 2020. Understanding of COVID-19 based on current evidence. Journal of Medical Virology 92(6): 548-551.

Valderas, J.M., Starfield, B., Sibbald, B., Salisbury, C. \& Roland, M. 2009. Defining comorbidity: Implications for understanding health and health services. Annals of Family Medicine 7(4): 357-363.

Vankadari, N. \& Wilce, J.A. 2020. Emerging Wuhan (COVID-19) coronavirus: Glycan shield and structure prediction of spike glycoprotein and its interaction with human CD26. Emerging Microbes \& Infections 9(1): 601-604.

Volz, E., Hill, V., McCrone, J.T., Price, A., Jorgensen, D., O'Toole, Á., Southgate, J., Johnson, R., Jackson, B., Nascimento, F.F., Rey, S.M., Nicholls, S.M., Colquhoun, R.M., Filipe, A.S., Shepherd, J., Pascall, D.J., Shah, R., Jesudason, N. \& Connor, T.R. 2020. Evaluating the effects of SARS-CoV-2 Spike mutation D614G on transmissibility and pathogenicity. Cell 184(1): 64-75.

Wagner, C., Roychoudhury, P., Hadfield, J., Hodcroft, E.B., Lee, J., Moncla, L.H., Müller, N.F., Behrens, C., Huang, M.L., Mathias, P., Pepper, G., Shrestha, L., Hong, X., Neher, R.A., Baird, G.S., Greninger, A.L., Jerome, K.R. \& Bedford, T. 2020. Comparing viral load and clinical outcomes in Washington State across D614G mutation in spike protein of SARS-CoV-2. GitHub https://github.com/blab/ncov-wad614g. 
Wang, C., Liu, Z., Chen, Z., Huang, X., Xu, M., He, T. \& Zhang, $Z$. 2020. The establishment of reference sequence for SARS$\mathrm{CoV}-2$ and variation analysis. Journal of Medical Virology 92(6): 667-674.

Wang, D., Hu, B., Hu, C., Zhu, F., Liu, X., Zhang, J. \& Peng, Z. 2020. Clinical characteristics of 138 hospitalized patients with 2019 novel coronavirus-infected pneumonia in Wuhan, China. JAMA 323(11): 1061-1069.

Wang, L.S., Wang, Y.R., Ye, D.W. \& Liu, Q.Q. 2020. A review of the 2019 novel coronavirus (COVID-19) based on current evidence. International Journal of Antimicrobial Agents 55(6): 105948

Williams, R., Karuranga, S., Malanda, B., Saeedi, P., Basit, A., Besançon, S., Bommer, C., Esteghamati, A., Ogurtsova, K., Zhang, P. \& Colagiuri, S. 2020. Global and regional estimates and projections of diabetes-related health expenditure. Results from the International Diabetes Federation Diabetes Atlas, 9th edition. Diabetes Research and Clinical Practice 162: 108072.

Wu, C., Chen, X., Cai, Y., Xia, J., Zhou, X., Xu, S., Huang, H., Zhang, L., Zhou, X., Du, C., Zhang, Y., Song, J., Wang, S., Chao, Y., Yang, Z., Xu, J., Zhou, X., Chen, D., Xiong, W., Xu, L., Zhou, F., Jiang, J., Bai, C., Zheng, J. \& Song, Y. 2020a. Risk factors associated with acute respiratory distress syndrome and death in patients with coronavirus disease 2019 pneumonia in Wuhan, China. JAMA 180(7): 934.

Wu, J.T., Leung, K., Bushman, M., Kishore, N., Niehus, R., de Salazar, P.M., Cowling, B.J., Lipsitch, M. \& Leung, G.M. 2020b. Estimating clinical severity of COVID-19 from the transmission dynamics in Wuhan, China. Nature Medicine 26(4): 506-510

Wu, J.T., Leung, K. \& Leung, G.M. 2020c. Nowcasting and forecasting the potential domestic and international spread of the 2019-nCoV outbreak originating in Wuhan, China: A modelling study. The Lancet 395(10225): 689-697.

Yan, R., Zhang, Y., Li, Y., Xia, L., Guo, Y. \& Zhou, Q. 2020. Structural basis for the recognition of SARS-CoV-2 by fulllength human ACE2. Science 367(6485): 1444-1448.

Young, B.E., BChir, M.B., Fong, S.W., Chan, Y.H., Mak, T.M., Ang, L.W., Anderson, D.E., Lee, C.Y.P., Siti Naqiah Amrun, Lee, B., Goh, Y.S., Su, Y.C.F., Wei, W.E., Shirin Kalimuddin, Chai, L.Y.A., Pada Surinder, Tan, S.Y., Sun, L., Parthasarathy Purnima \& Ng, L.F.P. 2020. Effects of a major deletion in the SARS-CoV-2 genome on the severity of infection and the inflammatory response: An observational cohort study. Lancet (London, England) 396(10251): 603-611.

Yu, J., Tostanoski, L.H., Peter, L., Mercado, N.B., McMahan, K., Mahrokhian, S.H. \& Barouch, D.H. 2020. DNA vaccine protection against SARS-CoV-2 in rhesus macaques. Science 369(6505): 806-811.

Zare-Zardini, H., Soltaninejad, H., Ferdosian, F., Hamidieh, A.A. \& Memarpoor-Yazdi, M. 2020. Coronavirus disease 2019 (COVID-19) in children: Prevalence, diagnosis, clinical symptoms, and treatment. International Journal of General Medicine 13: 477-482.
Zhang, H., Penninger, J.M., Li, Y., Zhong, N. \& Slutsky, A.S 2020. Angiotensin-converting enzyme 2 (ACE2) as a SARS-CoV-2 receptor: Molecular mechanisms and potential therapeutic target. Intensive Care Medicine 46(4): 586-590.

Zhang, J.J., Dong, X., Cao, Y.Y., Yuan, Y.D., Yang, Y.B., Yan, Y.Q., Akdis, C.A. \& Gao, Y.D. 2020. Clinical characteristics of 140 patients infected with SARS-CoV-2 in Wuhan, China. Allergy 75(7): 1730-1741.

Zhang, L., Jackson, C.B., Mou, H., Ojha, A., Rangarajan, E.S., Izard, T., Farzan, M. \& Choe, H. 2020. The D614G mutation in the SARS-CoV-2 spike protein reduces $\mathrm{S} 1$ shedding and increases infectivity. bioRxiv 2020.2006.2012.148726.

Zhang, S., Diao, M., Yu, W., Pei, L., Lin, Z. \& Chen, D. 2020. Estimation of the reproductive number of novel coronavirus (COVID-19) and the probable outbreak size on the Diamond Princess cruise ship: A data-driven analysis. International Journal of Infectious Diseases: IJID: Official publication of the International Society for Infectious Diseases 93: 201-204.

Zheng, J. 2020. SARS-CoV-2: An emerging coronavirus that causes a global threat. International Journal of Biological Sciences 16(16): 1678-1685.

Zheng, Z., Peng, F., Xu, B., Zhao, J., Liu, H., Peng, J., Li, Q., Jiang, C., Zhou, Y., Liu, S., Ye, C., Zhang, P., Xing, Y. \& Guo, H. 2020. Risk factors of critical \& mortal COVID-19 cases: A systematic literature review and meta-analysis. Journal of Infection 81(2): e16-e25.

Zhou, F., Yu, T., Du, R., Fan, G., Liu, Y., Liu, Z., Xiang, J., Wang Y., Song, B., Gu, X., Guan, L., Wei, Y., Li, Hui., Wu, X., Xu, J., Tu, S., Zhang, Y., Chen, H. \& Cao, B. 2020. Clinical course and risk factors for mortality of adult in patients with COVID-19 in Wuhan, China: A retrospective cohort study. The Lancet 395(10229): 1054-1062.

Zhuang, M.W., Cheng, Y., Zhang, J., Jiang, X.M., Wang, L., Deng, J. \& Wang, P.H. 2020. Increasing host cellular receptorangiotensin-converting enzyme 2 (ACE2) expression by coronavirus may facilitate 2019-nCoV (or SARS-CoV-2) infection. Journal of Medical Virology doi: https://doi. org/10.1101/2020.02.24.963348.

Zisman, L.S., Meixell, G.E., Bristow, M.R. \& Canver, C.C 2003. Angiotensin-(1-7) formation in the intact human heart Circulation 108(14): 1679-1681.

Siti Asmaa Mat Jusoh, Parisa Foroozandeh, Lee Yan Fen, Mardani Abdul Halim, Manoj Kumar Laskmanan \& Shaharum Shamsuddin*

Universiti Sains Malaysia (USM)-RIKEN

Interdisciplinary Collaboration for Advanced Sciences (URICAS) 11700 Gelugor, Pulau Pinang

Malaysia

Siti Asmaa Mat Jusoh \& Shaharum Shamsuddin*

School of Health Sciences

Universiti Sains Malaysia

16150 Kubang Kerian, Kelantan Darul Naim

Malaysia 
Lee Yan Fen

School of Pharmaceutical Sciences

Universiti Sains Malaysia

11700 Gelugor, Pulau Pinang

Malaysia

Mardani Abdul Halim \& Manoj Kumar Laskmanan School of Biological Sciences

Universiti Sains Malaysia

11700 Gelugor, Pulau Pinang

Malaysia
Shaharum Shamsuddin*

Institute for Research in Molecular Medicine (INFORMM)

Universiti Sains Malaysia

16150 Kubang Kerian, Kelantan Darul Naim Malaysia

*Corresponding author; email: shaharum1@usm.my

Received: 25 November 2020

Accepted: 5 February 2021 